\title{
Road safety and metrology: what's binomial?
}

\author{
M. do Céu Ferreira ${ }^{\star}$ and A. Cruz ${ }^{\star \star}$ \\ Instituto Português da Qualidade, Rua António Gião, 2829-513 Caparica, Portugal
}

Received: 15 November 2009 / Accepted: 5 February 2010

\begin{abstract}
Efficient traffic enforcement requires a system characterized by regulations where metrology must have a significant role. It is important for competent authorities and manufacturers to have efficient measurement traceability within the framework of conformity assessment of instruments available on the market. Therefore a growing interest lies in the role of metrological decisions in conformity assessment, particularly where measurements are in support of safety and health, such as in road safety. This paper focuses on the role of Portuguese Legal Metrology in the field of road safety, it emphasizes the relevance of metrological control of some measuring instruments in the field of the National Program Strategic Plan for Road Safety, as a way to prevent and monitor the crash rate.
\end{abstract}

Keywords: Road safety; policy; legislation; metrology; measuring instruments

\section{Introduction}

Every year around one million people die as a result of traffic accidents worldwide. A 'human disaster' is the description often made of the global traffic safety situation with more than one million fatalities each year.

Several sectors of society are cooperating on transferring knowledge, and bringing together evidence based on strategies and countermeasures that will improve their market situation.

In the framework of the European Council (EU), all Member States are concerned with the same road safety problems, namely excessive speed, drinking and driving; failure to wear a seat belt, the insufficient protection provided by vehicles, accident black spots, non-compliance with driving and rest times by commercial drivers and poor visibility [1].

In that scope, 'the Road Safety Action Programme' (2003-2010) was implemented with the goal to reduce the number of people killed on the roads by half by 2010 .

The next Action Plan covers the period 2009/2014 and a mid-term review will take place in 2012/2013.

The Home State Secretary chairs The National Plan for Road Accident Prevention whose departure point was the average of the period 1998/2000 [2].

\section{Measuring instruments on road safety}

Metrology plays a major role in road safety. The contribution of metrology can be observed in various areas such as, vehicle safety, police checks, alcohol and drugs consumption detection, etc.

\footnotetext{
^ Correspondence: mcferreira@mail.ipq.pt

${ }^{\star \star}$ Correspondence: acruz@mail.ipq.pt
}

The science of measurement is part of a technical community as a whole, providing tools to ensure the reliability of the technologies used.

To the common user, these metrology tools can either be relevant or irrelevant, but for life safety, the improvement given by metrology is present every day and everywhere in the world. A simple example is the incorrect pressure of tyres that is a major risk for safety: this example presents a measurement system marked by a technology, where the metrological control intervenes through technical proceedings. Some other examples can be observed in Table 1.

Efficient policy enforcement requires harmonised approaches and trust is an inherent part of this process. In the aim of metrology, thrust means measurements traceability to SI (International System of Units) with a certain confidence level. Because many decisions are based on tests or measurements the reliability of the instruments must be proved before marketing, the applicable metrological requirements must be met and if the instruments are in use for some time they are subject to a reverification test. The instrument will be rejected after it is demonstrated that it is operating outside its metrological limits. According to the scope of Measuring Instruments Directive (MID), that is covered by National legislation Law-Decree No. 192/2006, the free trade of several types of measuring instruments is regularized, namely the construction and certification procedures.

On the framework of road safety (Tab. 1) and MID, the instruments that measure vehicle exhaust emissions were the only ones covered by MID. For the other instruments, the type approval and verification requirements for each component of an enforcement system are based on specific national legislation (see Sect. 2.1). Special attention must be given to all systems including software, to 
Table 1. Application of OIML Recommendations on road safety enforcement.

\begin{tabular}{|c|c|c|}
\hline OIML R & Application & Metrological function \\
\hline $\begin{array}{l}\text { 23: } \\
\text { Tyre pressure } \\
\text { gauges for } \\
\text { motor vehicles }\end{array}$ & $\begin{array}{l}\text { Define the metrological } \\
\text { characteristics to } \\
\text { which pressure gauges } \\
\text { intended for the } \\
\text { measurement of the } \\
\text { inflation pressures in } \\
\text { motor-vehicle tyres } \\
\text { must conform. }\end{array}$ & $\begin{array}{l}\text { Measure directly the } \\
\text { influence of a mechanical } \\
\text { transmission and the } \\
\text { elastic deformation of a } \\
\text { sensing element. }\end{array}$ \\
\hline $\begin{array}{l}55: \\
\text { Speedometers, } \\
\text { mechanical } \\
\text { odometers and } \\
\text { chronotachographs } \\
\text { for motor vehicles }\end{array}$ & $\begin{array}{l}\text { Define the } \\
\text { metrological } \\
\text { regulations of } \\
\text { speedometer, } \\
\text { odometer and } \\
\text { chronotachograph. }\end{array}$ & $\begin{array}{l}\text { Measure the constant } k \text { of } \\
\text { odometer or } \\
\text { chronotachograph, } \\
\text { measure the coefficient } w \\
\text { of the vehicle. }\end{array}$ \\
\hline $\begin{array}{l}\mathbf{7 6 - 1} \& \mathbf{2 :} \\
\text { on-automatic } \\
\text { weighing } \\
\text { instruments }\end{array}$ & $\begin{array}{l}\text { Evaluate the metrological } \\
\text { and technical } \\
\text { characteristics of non- } \\
\text { automatic weighing } \\
\text { instruments that are } \\
\text { subject to official } \\
\text { metrological control. }\end{array}$ & $\begin{array}{l}\text { Measure the mass of a } \\
\text { body by using the action } \\
\text { of gravity on this body, } \\
\text { using the intervention of } \\
\text { an operator. }\end{array}$ \\
\hline $\begin{array}{l}\mathbf{9 1 :} \\
\text { Radar } \\
\text { equipment for } \\
\text { measuring the } \\
\text { speed of } \\
\text { vehicles }\end{array}$ & $\begin{array}{l}\text { State the conditions } \\
\text { that the microwave } \\
\text { Doppler radar must } \\
\text { satisfy when the } \\
\text { results of measurement } \\
\text { are to be used in legal } \\
\text { proceedings applied on } \\
\text { roads. }\end{array}$ & $\begin{array}{l}\text { Measure the angle of } \\
\text { incidence of the beam. }\end{array}$ \\
\hline $\begin{array}{l}\mathbf{9 9 - 1} \& \mathbf{2} \& \mathbf{3} \text { : } \\
\text { Instruments for } \\
\text { measuring } \\
\text { vehicle exhaust } \\
\text { emissions }\end{array}$ & $\begin{array}{l}\text { Check and maintain } \\
\text { in-use motor vehicles } \\
\text { with spark ignition } \\
\text { engines. }\end{array}$ & $\begin{array}{l}\text { Measure the volume } \\
\text { fraction of one or more of } \\
\text { the following exhaust gas } \\
\text { components: CO, } \mathrm{CO}_{2}, \mathrm{O}_{2} \text {, } \\
\mathrm{HC} \text { (in terms of n-hexane). }\end{array}$ \\
\hline $\begin{array}{l}\text { 126: } \\
\text { Evidential } \\
\text { Breath } \\
\text { Analyzers }\end{array}$ & $\begin{array}{l}\text { Define the } \\
\text { performance } \\
\text { requirements of EBA's } \\
\text { and the means and } \\
\text { methods employed in } \\
\text { testing them. }\end{array}$ & $\begin{array}{l}\text { Measure accurately and } \\
\text { display numerically the } \\
\text { breath alcohol mass } \\
\text { concentration of persons } \\
\text { (drivers, workers, etc.) } \\
\text { who may have consumed } \\
\text { alcohol. }\end{array}$ \\
\hline $\begin{array}{l}\text { 134-1 \& 2: } \\
\text { Automatic } \\
\text { instruments for } \\
\text { weighing road } \\
\text { vehicles in } \\
\text { motion and } \\
\text { measuring axle } \\
\text { loads }\end{array}$ & $\begin{array}{l}\text { Evaluate the } \\
\text { metrological and } \\
\text { technical requirements } \\
\text { of automatic weighing } \\
\text { instrument, having a } \\
\text { load receptor and } \\
\text { aprons, that } \\
\text { determines the vehicle } \\
\text { mass, axle loads. }\end{array}$ & $\begin{array}{l}\text { Measure the vehicle mass } \\
\text { and axle loads and if } \\
\text { applicable the axle-group } \\
\text { loads of a road vehicle } \\
\text { while the vehicle is } \\
\text { crossing over the load } \\
\text { receptor of the weighing } \\
\text { instrument. }\end{array}$ \\
\hline
\end{tabular}

ensure the integrity, authenticity and privacy of the data. Taking into account the specific national operating conditions, Member States should improve networks to support and harmonize the type of testing requirements.

The harmonization of regulations applied to metrological control by International Organization of Legal Metrology (OIML) has an important role. Some countries developed regulations based on OIML Recommendations, such as Portugal, where the metrological control of operations for some instruments is mandatory and a request for the National road code.

The role of metrology is also highlighted in some International Standards and European Directives. For example, the Directive 92/55/CEE emphasizes the measurements of motor vehicles emissions with technical support given by some International references, namely Standards 
No. 11614:1999 and 3930:2004 (last revision) from International Organization of Standardization (ISO). Other examples could be given for instruments that are directly related with road safety, such as tachographs (by Directive 2006/22/CE) and speed limitation devices through Directive 2004/11/CE, both covered by Portuguese legislation.

\section{Metrological control in Portugal}

Worldwide, the science of measurement plays a key role in underpinning activities, in all areas of science and technology, providing a fundamental basis for all human activity. Facing the global society, measurements have influence on the transparency of economic transactions, health and safety. For reasons of consumer protection and efficient manufacturing of measuring instruments, measurements are subjected to regulations by the core legislative body.

Within the framework of Portuguese Metrological System, a regulation was put in force that stipulates the operational procedures as well as the requirements of the National Legal System. According to Law-Decree No. 291/90 and the implementing order No. 962/90 that regulate and describe the Metrological Control of the measuring instruments in Portugal, these specific orders were implemented:

a) regulation No. 625/86, 25 of October: Tachographs;

b) law-decree No. 281/94, 11 of November and Law No. 46/2005 of 23 November: speed limitation devices;

c) regulation No. 797/97, 1 of September: apparatus for measurement of the opacity and for determination of the light absorption coefficient of exhaust gas;

d) regulation No. 389/98, 6 of July: tire pressure gauges for motor vehicles;

e) regulation No. 422/98, 21 of July: pressure Gauges;

f) law-decree No. 46/2005, 23 of February: speed limitation devices;

g) regulation No. 21/2007, 5 of January: instruments for measuring vehicle exhaust emissions;

h) regulation No. 1542/07, 6 of December: radar equipment for vehicles;

i) regulation No. 1556/2007, 10 of December: breath analyzers (EBA).

All new measuring instruments which are not covered by the Measuring Instruments Directive (MID) have to be type approved by the Portuguese Institute for Quality (IPQ). Before the instrument is used, a notified body verifies its accuracy. While in use the trader will be responsible for its ongoing maintenance, accuracy and correct use.

IPQ works closely with regional metrology offices and collaborates with manufacturers and suppliers.

According to the National legislation (list above), only breath analyzers and radar equipment for vehicles are verified directly by IPQ. The other instruments are verified by local authorities whose competence and supervision were given and carried out by IPQ.

\subsection{Alcohol and speed control}

The principal causes of fatal road accidents are related to driving a motor vehicle under the influence of alcohol and excessive speed. Because of this, the rules of police enforcement cover the road code by controlling drivers.

In this context, IPQ has a major role in improving the traceability of measuring instruments used by the police for controlling road drivers. Furthermore, measuring instruments used for evidential purposes on Portuguese roads, namely EBA and radar devices, must have Portuguese type approval as well as initial verification and subsequent annual verification.

\subsection{Evidential breath analyzers - EBA}

Evidential Breath Analysers are instruments that automatically measure the mass concentration of alcohol in exhaled breath. They can be used to measure accurately and display numerically the breath alcohol mass concentration of persons who may have consumed alcohol. Over the years, breath testing has become a widely used method for the qualitative and quantitative determination of the alcohol level of persons suspected of driving while under the influence of alcohol.

All over the world, scientists have started to look for new non-invasive methods to determine the alcohol concentration in the human body. Depending on the accuracy, specifically alcohol-related, cross sensitivity, long term stability, etc., a number of measuring principles are used for breath alcohol determination: chemical, bio-chemical (system based on oral fluids), physical (semiconductor cell surface reaction), electrochemical (fuel cell), infrared spectroscopy, and gas chromatography.

Breath-alcohol testing methods have changed over the years from chemical oxidation and calorimetric procedures to physic-chemical techniques such as gas chromatography, electrochemical oxidation and multiple wavelength infrared spectrophotometers. However, in the field of metrological control and the scope of Portuguese legislation, an EBA (IR spectrometry) has been adopted.

Its emphasis on police enforcement (road safety) is related to the estimation of $2 \%$ of all journeys across EU are associated with an illegal Blood Alcohol Concentration (BAC). In Portugal, the legal limit is $0.5 \mathrm{~g} / \mathrm{L} \mathrm{BAC}$, however, EU Member States have different legal limits for the values of BAC (Fig. 1).

Regarding these different limits, some countries have different penalties. According Portuguese Highway Code, the Administrative offence for drivers with alcohol excess is shown in Table 2.

The increasing BAC has on several psychomotor and effective behaviour patterns, directly related to the risk of accidents (Tab. 3).

In any case, it is mandatory for all EU Members States to carry out breath tests by the police and is advised to monitor the prevalence of drink driving.

Legal Metrology gives an input through Recommendation No. 126, which defines the performance requirements 


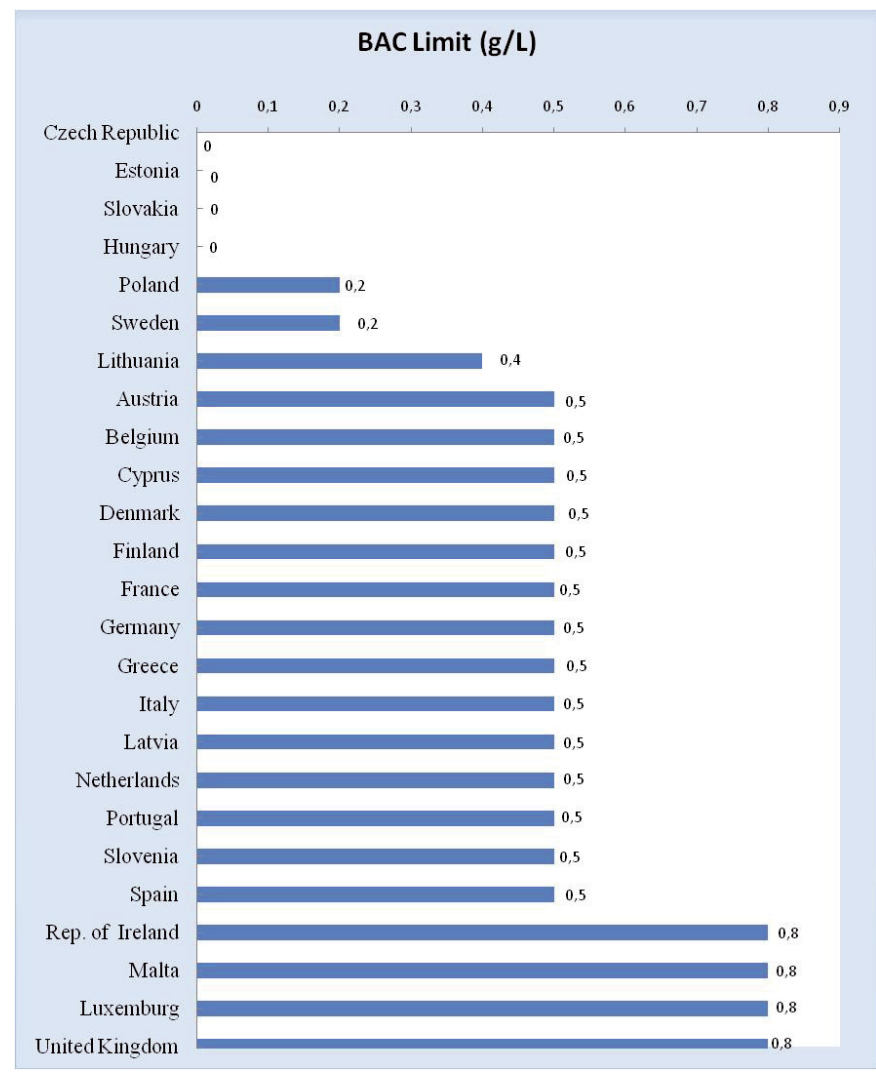

Fig. 1. Legal alcohol limits for driver population of EU-25.

Table 2. Limits of ordinance (Portuguese road code).

\begin{tabular}{|c|c|c|}
\hline $\mathrm{g} / \mathrm{L}$ & $\begin{array}{c}\text { Administrative } \\
\text { offense }\end{array}$ & Sanction \\
\hline $0.5 \leq \mathrm{BAC} \leq 0.8$ & Grievous & $\begin{array}{l}\text { Suspension of } \\
\text { driving licence } \\
\text { from one month to } \\
\text { one year/fine } \\
\text { between } € 250 \text { to } \\
€ 1250\end{array}$ \\
\hline $0.8 \leq \mathrm{BAC} \leq 1.2$ & Very grievous & $\begin{array}{l}\text { Suspension of } \\
\text { driving licence } \\
\text { from two months } \\
\text { to two years/fine } \\
\text { between } € 500 \text { to } \\
€ 2500\end{array}$ \\
\hline $\mathrm{BAC} \geq 1.2$ & Prison & \\
\hline
\end{tabular}

of EBA's as well as the means and methods employed in testing them.

All evidencial breath analysers are verified by IPQ according to OIML Recommendation [4].

\subsection{Speed control}

According to information from EU, speed is an essential contributory factor for around $30 \%$ of the fatal accidents.
Table 3. Alcohol and accident risks (source: [3]).

\begin{tabular}{cc}
\hline BAC $(\mathrm{g} / \mathrm{L})$ & $\begin{array}{c}\text { Probability to cause an } \\
\text { accident }\end{array}$ \\
\hline 0.6 & $2 \times$ as high \\
0.8 & $4 \times$ as high \\
1.0 & $6 \times$ as high \\
1.3 & $12 \times$ as high \\
\hline
\end{tabular}

Relationships have been established between speed and accident risk, such as the relation between a higher speed and the reaction time, injury consequences, etc.

International recommendations advise the measurement of traffic speed on roads must be performed by radar equipment.

In the framework of Portuguese Legislation, radar instruments are submitted to a metrological control, according to national order No. 1542/07 and Recommendation No. 91 of International Organization of Legal Metrology (OIML). By this approach, IPQ has carried out the type approval and periodic verifications of the microwave Doppler radar [5]. By emphasizing the traceability of the measurements, the legal interpretation of the results gives an assurance which allow using the instruments for the purpose of the police enforcement (rode code).

Speed limits are at the core of any speed management policy; moreover, current speed limit policies differ among countries. The general speed limit for motorways in EU Member States is generally 120 or $130 \mathrm{~km} / \mathrm{h}$, and for rural roads is 80 or $90 \mathrm{~km} / \mathrm{h}$ and for urban roads $50 \mathrm{~km} / \mathrm{h}$ (Tab. 4).

By EU-Directive 92/24/EEC and its recent adaptation (2004/11/EEC), speed limiters are compulsory for heavy goods vehicles (HGVs) of $3500 \mathrm{~kg}$ and more as well as for buses with $10000 \mathrm{~kg}$ or more. However, some countries apply lower values and bus speed limits for different road types.

\section{Improvement technology}

According to EU Recommendation about enforcement on traffic law [6], the three prioritized areas for improvement technology are speeding, drink driving and seat-belt buckling. Regarding the case of drink driving, some countries have implemented new devices for alcohol breath-testing-, designated by inter-locks, placed inside and connected to the vehicle [7]. The main feature of this type of device is to lock the vehicle ignition system unless the driver has performed a breath test. If the system indicates a breath alcohol concentration over the threshold level, it prevents the driver from driving.

Actually some countries have successfully implemented alcohol ignition interlock programme with a relevant progress in some sectors, such as commercial transport (school buses) and rehabilitation programs. Portugal has started the implementation of inter-locks, without a significant impact on society. These instruments are not covered by national metrological legislation but should be submitted to a calibration program in order to provide the 
Table 4. Road limits speed on EU roads (source: J.-P. Cauzard, SARTRE 3, 2005).

\begin{tabular}{lccc}
\hline & $\begin{array}{c}\text { In built-up } \\
\text { areas }(\mathrm{km} / \mathrm{h})\end{array}$ & $\begin{array}{c}\text { Outside built-up } \\
\text { areas }(\mathrm{km} / \mathrm{h})\end{array}$ & $\begin{array}{c}\text { Motorways } \\
(\mathrm{km} / \mathrm{h})\end{array}$ \\
\hline Austria & 50 & 100 & 130 \\
Belgium & 50 & 90 & 120 \\
Bulgaria & 50 & 90 & 130 \\
Cyprus & 50 & 80 & 100 \\
Czech & 50 & 90 & 130 \\
Republic & & & \\
Denmark & 50 & 80 & 110 or 130 \\
Estonia & 50 & 90 or 100 or 110 & - \\
France & 50 & 90 or 110 & 130 \\
Finland & 50 & 80 or 100 & 100 or 120 \\
Greece & 50 & 90 or 110 & 130 \\
Germany & 50 & 100 & $1300^{(*)}$ \\
Hungary & 50 & 90 or 110 & 130 \\
Italy & 50 & 90 or 110 & 130 \\
Ireland & 50 & 80 or 100 & 120 \\
Latvia & 60 & 90 & 100 \\
Luxembourg & 50 & 90 & 130 \\
Lithuania & 50 & 90 & 110 or 130 \\
Netherlands & 50 & $80-100$ & 120 \\
Malta & 50 & 80 & 100 \\
Poland & 50 & $90-110$ & 130 \\
Portugal & 50 & $90-100$ & 120 \\
Slovenia & 50 & 90 & 130 \\
Spain & 50 & 90 or 100 & 120 \\
Sweden & 50 & $70-90$ & 110 \\
United & 48 & 96 or 112 & 112 \\
Kingdom & $(30$ miles $)$ & $(60$ or 70 miles $)$ & $(70$ miles $)$ \\
\hline & & &
\end{tabular}

traceability to SI units. Furthermore, it covers some advances in road safety technology such as the integration of cameras into the device to identify the person who provided the breath sample.

In the scope of speeding, EU has proposed an action plan and European Directive for Intelligent Transport Systems (ITS). Intelligent Speed Adaptation (ISA) is an Intelligent Transport System (ITS) which informs the driver about speeding, discourages the driver from speeding or prevents the driver from exceeding the speed limit [8].

Since the human factor is the major risk factor in road safety, the developments of new technology will have to ensure already existing vehicle safety and make intelligible human/vehicle interfaces.

The European Action Plan suggests a number of targeted measures, and a proposal for a Directive lays down the framework for their implementation. The purpose is to ensure better use of the new active safety systems and advanced driver assistance systems with proven benefits in terms of in-vehicle safety for the vehicle occupants and other road users (including vulnerable road users). The Action Plan covers the period 2009/2014 and a mid-term review will take place in 2012/2013 [9].

\section{Conclusions}

As the science of measurement, metrology is present in our daily lives, serving the community as a holistic approach. Metrologists, as technical and scientific experts in several fields, can provide relevant improvements in multidisciplinary task groups. This kind of requisite experience should be a target, namely when a measurement system is on the forefront.

In order to improve solutions for detecting the risk of the drivers, Metrology should be seriously engaged where the risk factors are correctly identified, such as on alcohol and drugs consumption and high speed. The same approach could be drawn for the reduction of risks caused by environmental conditions of the vehicle. In addition, the direct involvement of metrology may prevent or decrease the driver's errors of evaluation, focused on the technology of the on-board computer and automatic cruise control. However, for an efficient enforcement of the binomial metrology/road safety, trust must be omnipresent, where trust, in this context, means the global acceptation of the results. A mutual recognition agreement for the technical aspects and prosecution process, with a whole application at the level of European legal framework should be mandatory.

The competent organizations should make more effort to improve the Metrologist involved in road safety research projects and other joint commissions. This is the binomial which plays a fundamental role in technology optimization and this is certainly where the future lies.

\section{References}

1. Road accident data in the enlarged European Union Learning from each other, European Transport Safety Council, Brussels (ETSC, 2006)

2. National Plan for Road Accident Prevention, Report of Ministry of Internal Affairs (2003)

3. R. Breitstadt, The worker-risk factor and reliability, Collection of facts for managers, Univ-Prof. Dr. G. Kauert (2004)

4. M.C. Ferreira, A. Cruz, Controlo Metrológico de Alcoolímetros no Instituto Português da Qualidade, Proceedings of the $2^{a}$ Conferência Nacional SPMET, 17 Novembro 2006, Lisboa, Portugal

5. M.C. Ferreira, O. Pellegrino A. Furtado, C.M. Pires, Controlo Metrológico dos alcoolímetros e cinemómetros no IPQ, Proceedings of the $2^{a}$ Conferência Nacional SPMET, 3-4 Outubro 2007, Funchal, Madeira

6. http://ec.europa.eu/enterprise/sectors/automotive/files/ consultation/2_3_wheelers/consultation_document_en.pdf

7. M. Drevet, Alcohol inter-lock Implementation in the European Union: An In-depth Qualitative Field, in Proceedings of the ICADTS Glasgow Conference (2004)

8. In-Car Enforcement Technologies Today, The European Transport Safety Council (ETSC, 2005)

9. www.etsc.eu/PIN-publications.php 